\title{
Development of agricultural land and water use and its driving forces along the Aksu and Tarim River, P.R. China
}

\author{
Til Feike $\cdot$ Yusuyunjiang Mamitimin • \\ Lin $\mathrm{Li} \cdot$ Reiner Doluschitz
}

Received: 19 July 2013/ Accepted: 27 January 2014/Published online: 2 March 2014

(C) The Author(s) 2014. This article is published with open access at Springerlink.com

\begin{abstract}
The extremely arid Aksu-Tarim Region (ATR) in northwestern China is one of the country's most important cotton production bases. However, in recent years, the negative ecological consequences of the intensive agricultural production become apparent. Apart from the degradation of riparian vegetation, competition for scarce water resources among farmers tightens. To be able to develop solutions for the aggravating problems, and sustain the ATR as a favored agricultural production base, it is decisive to clearly understand the land- and water-use development and its driving forces in the ATR. Statistical yearbook data from 1989 to 2011, comprising the four administrative regions of the ATR, namely Aksu and Bayangol prefectures, as well as Division 1 and Division 2 of the military farms, and annual producer price data constitute the data base for the present study. Relevant policy documents and data obtained through a stakeholder workshop complement the analysis. It is shown that agricultural land area more than doubled during the 1989-2011 period. This is a result of the interaction of: (1) vast population growth and related increase in agricultural labor; (2) positive price developments for fruits and cotton; (3) strong increase in agricultural profitability, triggering further land reclamation; (4) afforestation programs pushing
\end{abstract}

T. Feike $(\bowtie) \cdot$ Y. Mamitimin · R. Doluschitz

Computer Applications and Business Management

in Agriculture, Institute of Farm Management,

Universität Hohenheim, 70593 Stuttgart, Germany

e-mail: tilfeike@uni-hohenheim.de

URL: https://www.uni-hohenheim.de/person/til-feike\#lsftabs-1

L. Li

College of Water Resources and Architectural Engineering,

Tarim University, Ala'er, Xinjiang 843300,

People's Republic of China

e-mail: lilinsj@126.com for the establishment of orchards; and (5) insufficient restriction of agricultural land expansion. It is recommended to step up the efforts to move people out of agriculture into other sectors, and significantly improve agricultural water productivity by increasing yield levels and shifting crop production towards labor-intensive high-value commodities.

Keywords Land-use change - Water use .

Driving forces - Tarim River - Xinjiang · China

\section{Introduction}

The Aksu-Tarim Region (ATR) is located in the southern part of Xinjiang Uighur Autonomous Region (XUAR) in Northwestern China. In the extremely arid ATR the Tarim River and its main tributary the Aksu, which are nourished by snow and glacier melt from the Tianshan Mountains, constitute the major water source for human activities and natural ecosystems (Fig. 1) (de la Paix et al. 2012). The Aksu headstreams actually rise on Kyrgyz territory; however, with up-to-date insignificant human water consumption along the Kyrgyz part of Aksu River only Chinese territory is considered for the present study.

The ATR comprises four administrative regions, which include two prefectures, namely Aksu Administrative Offices (hereafter referred to as Aksu) in the west and Bayangol Mongol Autonomous Prefecture (hereafter referred to as Bayangol) in the east, as well as two divisions of the Xinjiang Construction and Production Corps (XPCC), namely Division 1 (Div.1) and Division 2 (Div.2). The XPCC, established by the Beijing government in the 1950s to develop and stabilize the frontier regions in the Northwest, is a separate administrative unit within the area of XUAR (XPCCIO 2010). Of its 14 divisions two are 


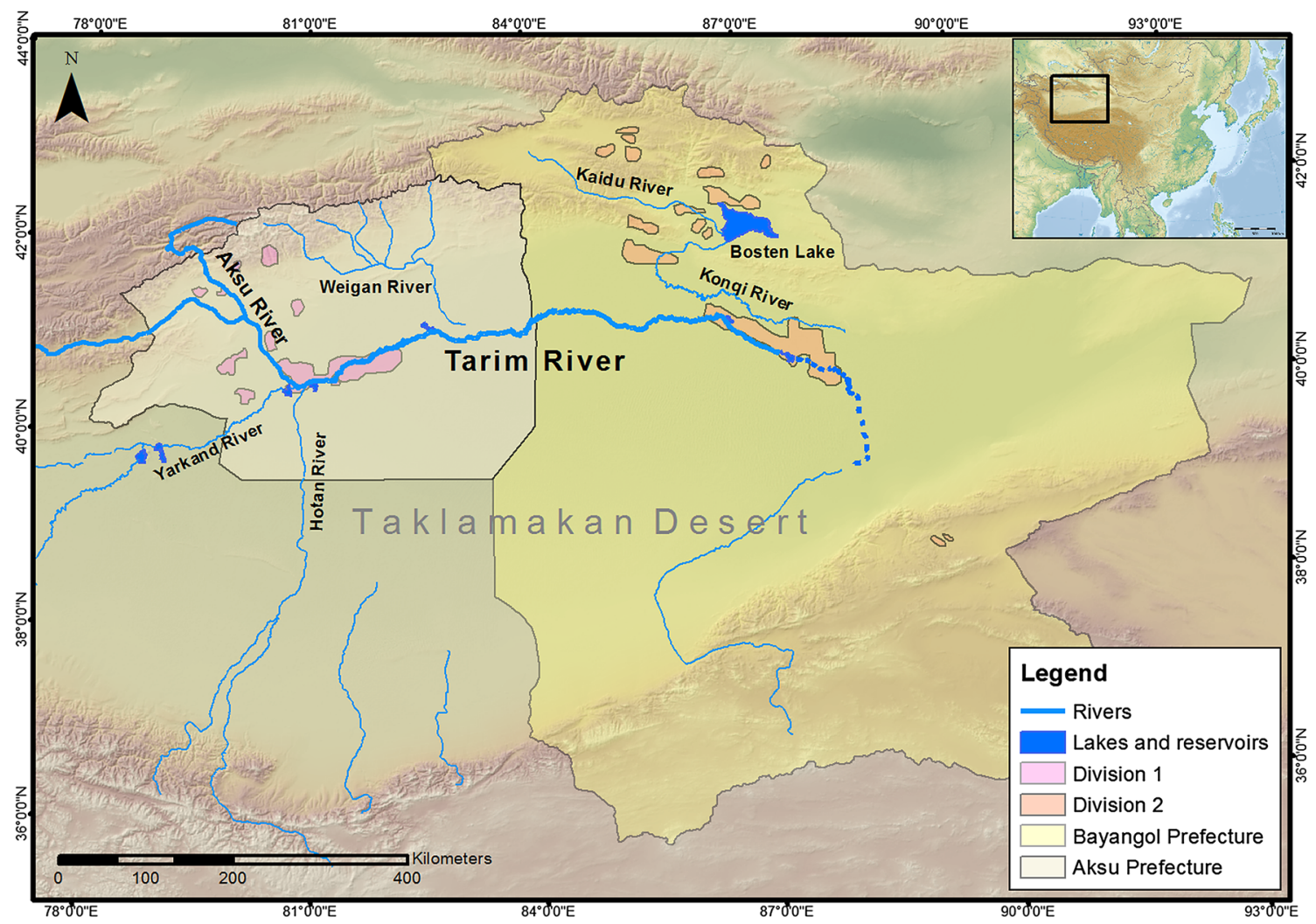

Fig. 1 The Aksu-Tarim Region with the location of Aksu and Bayangol prefecture, as well as Division 1 and Division 2 of the Xinjiang production and construction corps

located within the ATR, Div.1 in the lower Aksu region and Div.2 along the lower reaches of Tarim River.

The ATR is an important agricultural production region, contributing significantly to national cotton, grain and fruit supply (CSYB 2012; XJSYB 2012). The absence of rainfall coupled with abundant sunshine provides ideal cultivation conditions especially for cotton. However, in recent years the negative ecological consequences of the intensive agricultural production became apparent (Hao et al. 2010). In addition to the degradation of riparian vegetation, the overuse of surface and groundwater for irrigation of crops also led to an increased competition for water among farmers, often resulting in yield losses (Thevs 2011). Since the beginning of the twentieth century several research groups studied the water resource issue of the Tarim region, with a strong focus on the development of the hydrological situation within the basin (e.g., Bai et al. 2013; Turak et al. 2007; Xu et al. 2005), being influenced by climate change and human activities (e.g., Liu et al. 2013; Zhang 2001; Zhou et al. 2012), as well as its impact on the natural ecosystems (e.g., Hao et al. 2010; Xu et al. 2003; Zhang et al. 2003). To improve the ecological situation in the region, the existing body of literature concludes that the irrational use of water resources related to the tremendous increase of irrigation agriculture, needs to be strongly reduced, by improving agricultural water-use efficiency (e.g., Zhang
2001), to be achieved through extensive implementation of effective water-saving technologies (e.g., Chen et al. 2011).

However, the actual causes of the vast expansion of agricultural land area are heavily under investigated. To be able to develop more specific recommendations for overcoming the aggravating problems, it is vital to clearly understand the specific factors, which triggered the agricultural land expansion and related water use in recent decades. Therefore, the present publication analyses the development of agricultural land and water use, as well as its driving forces within the four administrative regions of the ATR. To be able to develop meaningful recommendations regarding future land and water-use management, the analysis focuses on the recent two decades comprising the timespan from 1989 to 2011.

\section{Materials and methods}

To identify and rate driving forces of water and land-use development in the ATR, an expert workshop was conducted in Xinjiang's provincial capital Urumqi in August 2011. Experts from all major research institutions including academies and universities, which are involved in research on water use in agriculture as well as extension specialists, participated in the workshop. 
Furthermore, statistical yearbooks, which constitute the major source of publicly available secondary data in China, were analyzed to clearly understand the historic developments of agricultural land and water use, and their respective driving forces. The database comprises the Xinjiang Statistical Yearbooks and Bingtuan Statistical Yearbooks from 1990 until 2012, which feature data from 1989 until 2011. Additionally, national producer price developments of major agricultural commodities, obtained from FAOSTAT were integrated in the analysis.

Moreover, relevant policy documents, first of all the recent and current "Five-year plans" (FYP) at prefectural and division level, as well as subject-related official ordinances were investigated to grasp the general policy orientation and specific intents related to agricultural land and water use in the respective administrative regions. The actual realization of the FYPs' policy targets were assessed by counterchecking against the yearbook data of the respective years. Finally, secondary scientific literature was utilized to evaluate and integrate the research findings.

\section{Results and discussion}

In this section we describe the development of agricultural land and water use, followed by a section which elaborates the driving forces responsible for those developments, while the third section analyses water-use efficiency and
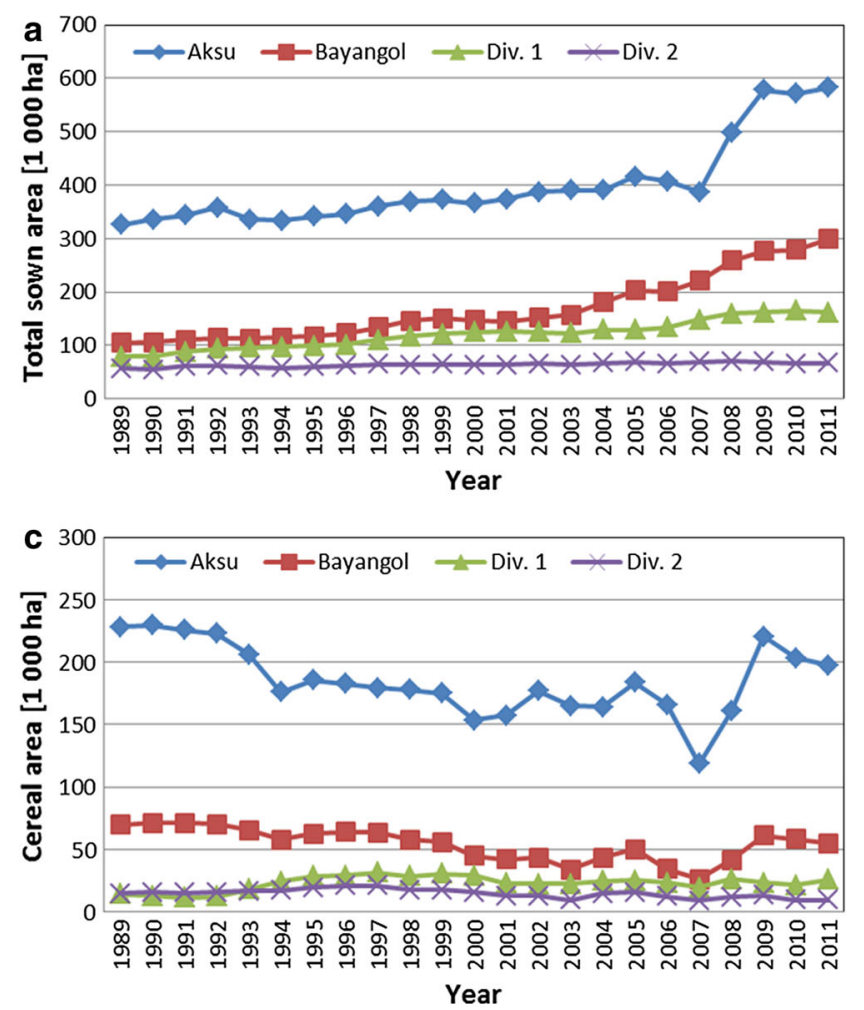

related water productivity, which are key variables for future water resource use planning.

Agricultural land-use development

\section{Area of annual crops}

A huge expansion of agricultural land-use area can be observed throughout the ATR from 1989 to 2011. The total area of annual crops increased very strongly in Aksu, Bayangol and Div. 1 in the last 22 years, while the area in Div. 2 hardly increased (Fig. 2a). The increases outside the military farms were much stronger, rising rapidly from 2004 and 2008 onwards in Bayangol and Aksu, respectively. The major annual crop is cotton, which experienced tremendous increases in sown area in all regions (Fig. 2b), while the area under cereal production stagnated at the same time (Fig. 2c). When looking at the area under vegetable cultivation (Fig. 2d), one can observe a sharp increase since the late 1990s in Aksu, Bayangol and Div.2, with vegetables occupying a relatively high share of cultivated land in Bayangol (14\%) and Div.2 (24\%) in 2011, compared to Aksu (4\%) and Div.1 (2\%).

\section{Area of perennial species}

Additionally, the area of orchards experienced a tremendous increase since the beginning of the new century
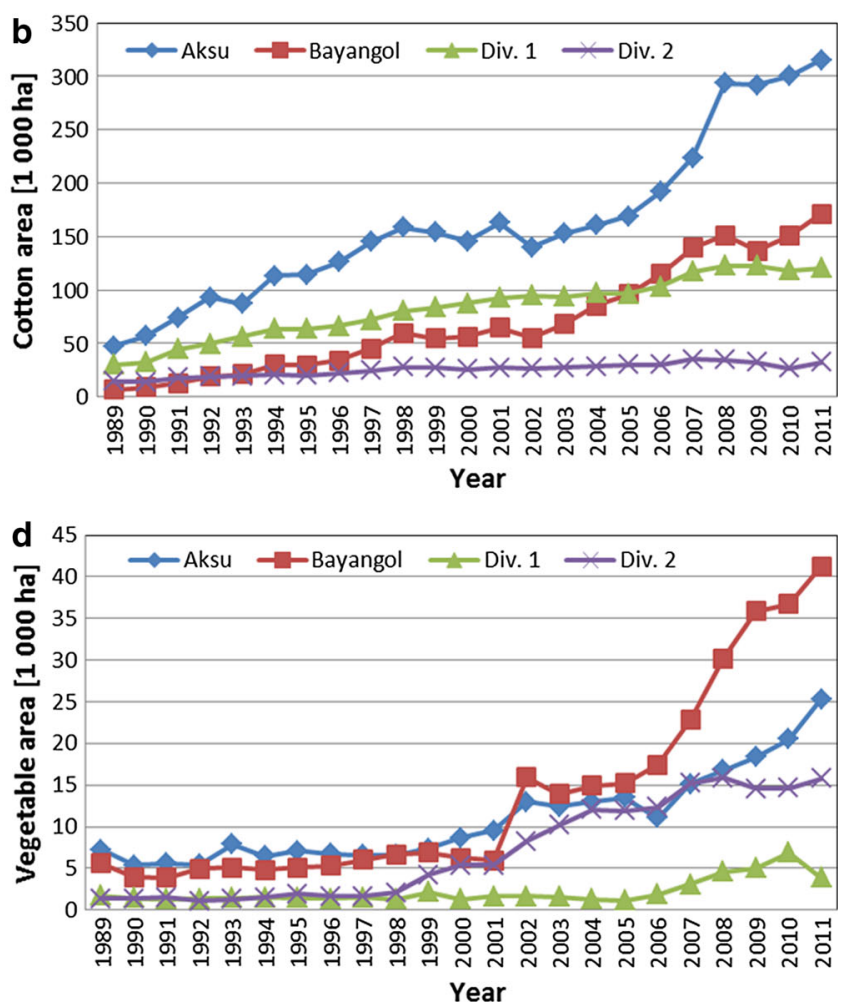

Fig. 2 Sown area of all annual crops (a), cotton (b), cereals (c) and vegetables (d) in four administrative regions of the ATR during 1989-2011 (compiled from BTSYB 1990-2012 and XJSYB 1990-2012) 
(Fig. 3a). Both absolute and relative increase is strongest in Aksu, followed by Bayangol, Div.1 and Div.2. Since 2005 jujube (Ziziphus jujuba Mill.), endemic to the arid regions of Northwestern China, and thus adapted to low humidity and high temperatures ( $\mathrm{Su}$ and Liu 2005), increased very rapidly, superseded pear and apricot in importance, and is by far the major fruit crop in the ATR in 2011 (BTSYB 1990-2012; XJSYB 1990-2012).

The upstream areas of ATR, namely Aksu and Div.1 feature a huge increase in afforestation area, while the area is much smaller in the downstream regions of Bayangol and Div.2 (Fig. 3b). The strong fluctuations in reported area are mainly caused by poor maintenance and related water shortage of newly established afforestation areas (Cao et al. 2011). While this area is reported as man-made forest in the year of planting, it is taken out of the accounts in the following years due to actual failure of establishment of forest (Yue and Su 2002).

\section{Water-use development}

Regarding agricultural water-use development only data of Aksu and Bayangol is available from 2004 onwards (Table 1). Until 2010 just a very marginal increase of total water supply is reported for both regions, while the amount of supplied surface water even decreased. Groundwater only contributed little to total water supply in the past. However, from 2004 to 2010 its share in total supply increased from 2 to $7 \%$ in Aksu and from $9 \%$ to more

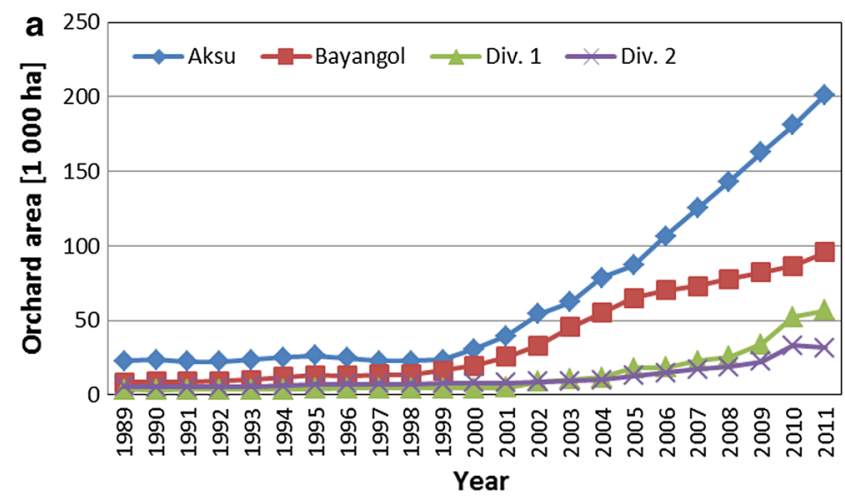

than $20 \%$ in Bayangol, indicating its increasing importance.

Among the three sectors agriculture is the major consumer of water resources with a share of $97 \%$ in Aksu and $93 \%$ in Bayangol in 2010 (Table 2). However, a slight decrease in the share of agriculture can be observed in both regions in recent years.

Even though the developments reported for Aksu and Bayangol for the 2004-2010 period indicate that agricultural water use did not increase in recent years, these data do not reflect the actual developments in the entire ATR over the last decades.

With average precipitation in the region being far below $100 \mathrm{~mm}$ ( $\mathrm{Xu}$ et al. 2005), all agricultural production as well as man-made forest cultivation inevitably depends on additional irrigation. Therefore, the rapid expansion of agricultural land, described in detail above, should have led to an increase of agricultural water consumption at a similar pace, which is confirmed by several studies. According to Thevs (2011), reclamation of new land steadily increased the withdrawal of irrigation water along the Tarim River and its tributaries. Tang and Deng (2010) describe a huge increase of water abstraction in the Aksu region between 1957 and 2002, which is also confirmed by Zhang (2001) for the 1990s to 2000s. Furthermore, Xu et al. (2005) quantified surface water withdrawal from Aksu River at 69 and 80 million $\mathrm{m}^{3}$ in 1994 and 2003, respectively, indicating that agricultural water use actually increased very strongly in the ATR.

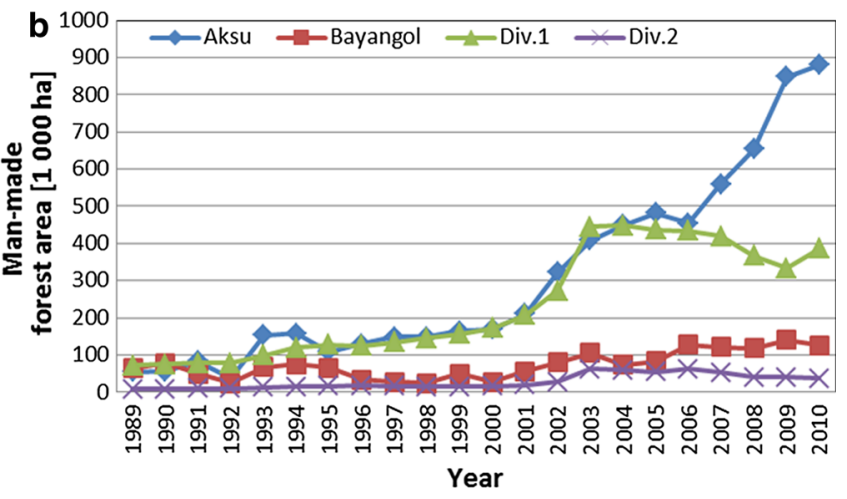

Fig. 3 Planted areas of orchards (a) and man-made forest (b) in four administrative regions of the ATR during 1989-2011 (compiled from BTSYB 1990-2012 and XJSYB 1990-2012)

Table 1 Development of total, groundwater and surface water supply in Aksu and Bayangol 2004-2010 (compiled from XJSYB 1990-2012)

\begin{tabular}{|c|c|c|c|c|c|c|}
\hline \multirow[t]{3}{*}{ Year } & \multicolumn{6}{|c|}{ Water supply by source $\left(10^{8} \mathrm{~m}^{3}\right)$} \\
\hline & \multicolumn{2}{|l|}{ Total } & \multicolumn{2}{|c|}{ Surface water } & \multicolumn{2}{|c|}{ Groundwater } \\
\hline & Aksu & Bayangol & Aksu & Bayangol & Aksu & Bayangol \\
\hline 2004 & 100.08 & 40.63 & 98.07 & 36.89 & 2.01 & 3.68 \\
\hline 2010 & 100.24 & 44.10 & 93.19 & 35.04 & 7.05 & 9.01 \\
\hline Annual increase (\%) & 0.03 & 1.42 & -0.83 & -0.84 & 41.79 & 24.14 \\
\hline
\end{tabular}


Table 2 Development of water consumption for all sectors and agriculture in Aksu and Bayangol 2004-2010 (compiled from XJSYB 2005-2012)

\begin{tabular}{|c|c|c|c|c|c|c|}
\hline \multirow[t]{3}{*}{ Year } & \multicolumn{4}{|c|}{ Water consumption $\left(10^{8} \mathrm{~m}^{3}\right)$} & \multirow{2}{*}{\multicolumn{2}{|c|}{ Share of agriculture (\%) }} \\
\hline & \multicolumn{2}{|c|}{ All sectors } & \multicolumn{2}{|c|}{ Agriculture } & & \\
\hline & Aksu & Bayangol & Aksu & Bayangol & Aksu & Bayangol \\
\hline 2004 & 99.36 & 38.53 & 98.45 & 37.76 & 98.37 & 92.94 \\
\hline 2010 & 98.49 & 42.33 & 97.50 & 40.90 & 97.27 & 92.74 \\
\hline Annual increase $(\%)$ & -0.15 & 1.64 & -0.16 & 1.39 & -0.19 & -0.03 \\
\hline
\end{tabular}

\section{Driving forces}

In the following section the driving forces of land and water use in the ATR and their developments are assessed.

\section{Stakeholder ranking}

Driving forces of regional land- and water-use development as identified and ranked by local experts during stakeholder workshop are presented in Table 3. The local experts rated population development and water resource availability as the strongest driving forces, followed by the development of agricultural yields, the technological progress regarding water-use efficiency and the overall economic development in the region. Furthermore, the developments of agricultural product quality as well as agricultural input and commodity prices are considered to have an impact on the regional development.

In the next step, the driving forces were categorized by the authors according to thematic focus, namely demographic, socio-economic, technological and natural factors. The developments of those categories of driving forces over the last two decades are illustrated and analyzed in the following chapters.

Demographic development

\section{Population growth}

Population growth was also identified as a major driving force for agricultural land expansion and related water consumption by Zhang et al. (2003) and Zhou et al. (2003) for different parts of arid Northwestern China, as well as by Wang et al. (2008) for the middle reaches of Tarim River. Looking at the statistical data, population in the ATR increased steadily at a high rate in Aksu, Bayangol and Div.1 since 1989, while it stagnated in Div.2 (Table 4).

When distinguishing between ethnicities, one can see that all groups contributed strongly to population growth. However, the causes of this massive increase have to be differentiated between the different ethnicities; Uighurs and other ethnic minorities (e.g., Kazak, Kirgiz, Mongol) feature a very high fertility. For those minorities one-child-policy does not apply in the same strictness as for the Han, who
Table 3 Driving forces of land and water use in the ATR evaluated by local experts during stakeholder workshop

\begin{tabular}{lll}
\hline Category & Regional driving force & $\begin{array}{l}\text { Importance } \\
(1=\text { weak, }\end{array}$ \\
& & $\begin{array}{l}5=\text { strong; } \\
N=10)\end{array}$ \\
\hline Demographic & Population development & 4.5 \\
Socio-economic & Economic development & 4 \\
& World market prices & 3.2 \\
& Agricultural input prices & 3.1 \\
& Trade (to west) & 3.1 \\
& Food demand & 3 \\
& Bio-energy demand & 1.6 \\
Natural & Availability of water resources & 4.5 \\
& Availability of land & 3.7 \\
& Climate change & 3.3 \\
Technological & Agricultural yields & 4.1 \\
& Technological progress (WUE) & 4.1 \\
& Product quality & 3.7 \\
\hline
\end{tabular}

constitute the national majority. While minorities were allowed to have up to four children in the beginning of the 1990s (Attane and Courbage 2000), the regulations were tightened since the early 2000s, and nowadays allow two children in urban areas and up to three children in rural areas (NHFPC 2002). In comparison, Han can generally only have one and two children in urban and rural areas, respectively. Hence the tremendous increase in Han population in the ATR since 1989 is not the result of high fertility, but is caused by immigration. This is on one side due to the central government's policy of encouraging people to settle in the frontier areas since the early 1950s, aiming at stabilizing and strengthening those often minority-dominated regions (Cote 2011). On the other side, the implications of the "Develop the West" policies and related positive economic and trading possibilities encouraged hundreds of thousands of people to move from other parts of China to Xinjiang since the 1990s. This development is further amplified by the relaxation of the household registration system in recent years (Fan 2005). Zhao et al. (2013) confirm those findings in a GIS study that spans over the 1973-2005 period. They identified population growth caused by migration as a dominant driver for land cover change along the Tarim River. 
Table 4 Development of population in four administrative regions and development of different ethnic groups in the entire ATR during 1989-2011 (compiled from BTSYB 1990-2012 and XJSYB 1990-2012)

\begin{tabular}{|c|c|c|c|c|c|c|c|}
\hline \multirow[t]{2}{*}{ Year } & \multicolumn{4}{|c|}{$\begin{array}{l}\text { Total population per sub-region } \\
\left(10^{4} \text { person }\right)\end{array}$} & \multicolumn{3}{|c|}{$\begin{array}{l}\text { Population per ethnicity in ATR } \\
\left(10^{4} \text { person }\right)\end{array}$} \\
\hline & Bayangol & Aksu & Div.1 & Div. 2 & Han & Uighur & Others \\
\hline 1989 & 82.4 & 164.2 & 18.3 & 18.8 & 110.5 & 161.5 & 11.8 \\
\hline 2011 & 136.6 & 258.1 & 29.7 & 19.1 & 189.7 & 236.0 & 17.8 \\
\hline Annual increase $(\%)$ & 3.0 & 2.6 & 2.8 & 0.1 & 3.3 & 2.1 & 2.3 \\
\hline
\end{tabular}

It that context it is important to recognize the awareness among local governments of rapid population growth being a major threat to sustainable development. Throughout the recent FYPs the governments' efforts to slow down population increase can be found, with the "implementation of family planning policy" and "stabilization of fertility level" strongly emphasized (e.g., DRCAP DRCAP 2006; DRCBP DRCBP 2006; DRCDO 2011). However, efforts to reduce immigration cannot be found. This may also be one reason, why the targeted population development was strongly exceeded in Aksu and Bayangol within the 11th FYP period (Table 5). The population decline in Div. 2 is mainly a result of lacking water resources and related poor development conditions, elaborated in more detail below. For Div.1 no data were available.

\section{Agricultural employment}

Not only the development of population, but also the number of people depending on agriculture for their living has strong impact on agricultural land and water resource use (Barbier 2004). Therefore, Fig. 4 displays the development of employment in agriculture and related issues in the ATR. The employment in agricultural sector approximately doubled in Aksu and Bayangol since 1989 (Fig. 4a), while it maintained at a stable level in Div.1 and Div.2. A slight decline in the share of agricultural employment in total employment over the last 22 years can be observed. The agricultural employment per agricultural land area decreased constantly in Bayangol, Div.1 and Div.2 from around 0.8 person per hectare in 1989 to around 0.4 person per hectare in 2011. Only in Aksu the ratio hardly declined staying above 0.8 person per hectare in 2011 .

It should be acknowledged that the local governments realized the importance of moving labor out of agriculture to alleviate the pressure on natural resources, recognizing "surplus labor force" (DRCDO 2011), "transfer of rural labor to urban areas" (DRCAP 2006) and "guide agricultural labor to non-agricultural industries" (DRCDT 2006). This shall be implemented by developing more job opportunities, especially in the construction and industrial sector (e.g., DRCAP 2006), recruiting local labor (e.g., DRCBP 2011), and improving the skills of local labor force through expansion of vocational training (e.g., DRCDO 2011).
Table 5 Planned vs. actual natural annual population growth for the four administrative regions of the ATR during the 11th FYP period (2006-2010) (compiled from BTSYB 2011; DRCAP 2006; DRCBP 2006; DRCDT 2006; XJSYB 2011)

\begin{tabular}{lrrrr}
\hline 2006-2010 & \multicolumn{4}{c}{ Natural annual population growth (\%) } \\
\cline { 2 - 5 } & Aksu & Bayangol & Div.1 & \multicolumn{1}{c}{ Div.2 } \\
\hline Planned & 12.0 & 8.5 & nn & 30.0 \\
Actual & 19.1 & 23.6 & 2.0 & -16.7 \\
Planned vs. actual (\%) & +59.5 & +177.5 & $\mathrm{nn}$ & -155.8 \\
\hline
\end{tabular}

In the context of agricultural labor, the mechanization of farm management, which is rapidly advancing throughout China (Feike et al. 2012), needs to be considered. Mechanization, displayed as total power of agricultural machinery per hectare in Fig. 4d, increased strongly in all four regions of the ATR. The lowest level of mechanization is found in Aksu, while Bayangol features the highest rate.

Socio-economic development

\section{Gross output value of farming}

Zhang (2004) identified economic development as the strongest trigger for land reclamation in the Yangtze River Basin, while Wang et al. (2007) attributed a great share of land-use change in Qinghai Province to be driven by economic development. This is in line with the findings of Yang and Li (2000), who stress the impact of economic development as a major driver of land-use change on national level. In the ATR profound changes can be observed looking at the economic development of agricultural sector. The total gross output value (GOV) of agriculture increased from 16 million RMB to 246 million RMB from 1989 to 2011 (Fig. 5a). This has to be acknowledged as a great achievement, contributing considerably to the improvement of rural livelihoods in the region. Rapid increases occurred in Aksu, Bayangol and Div.1 especially from 2000 onwards. Div. 2 shows a significantly lower increase compared to the other three regions. The share of farming, meaning crop and fruit production, makes up the major part of total agricultural GOV (Fig. 5b), while livestock, fishery, forestry and 

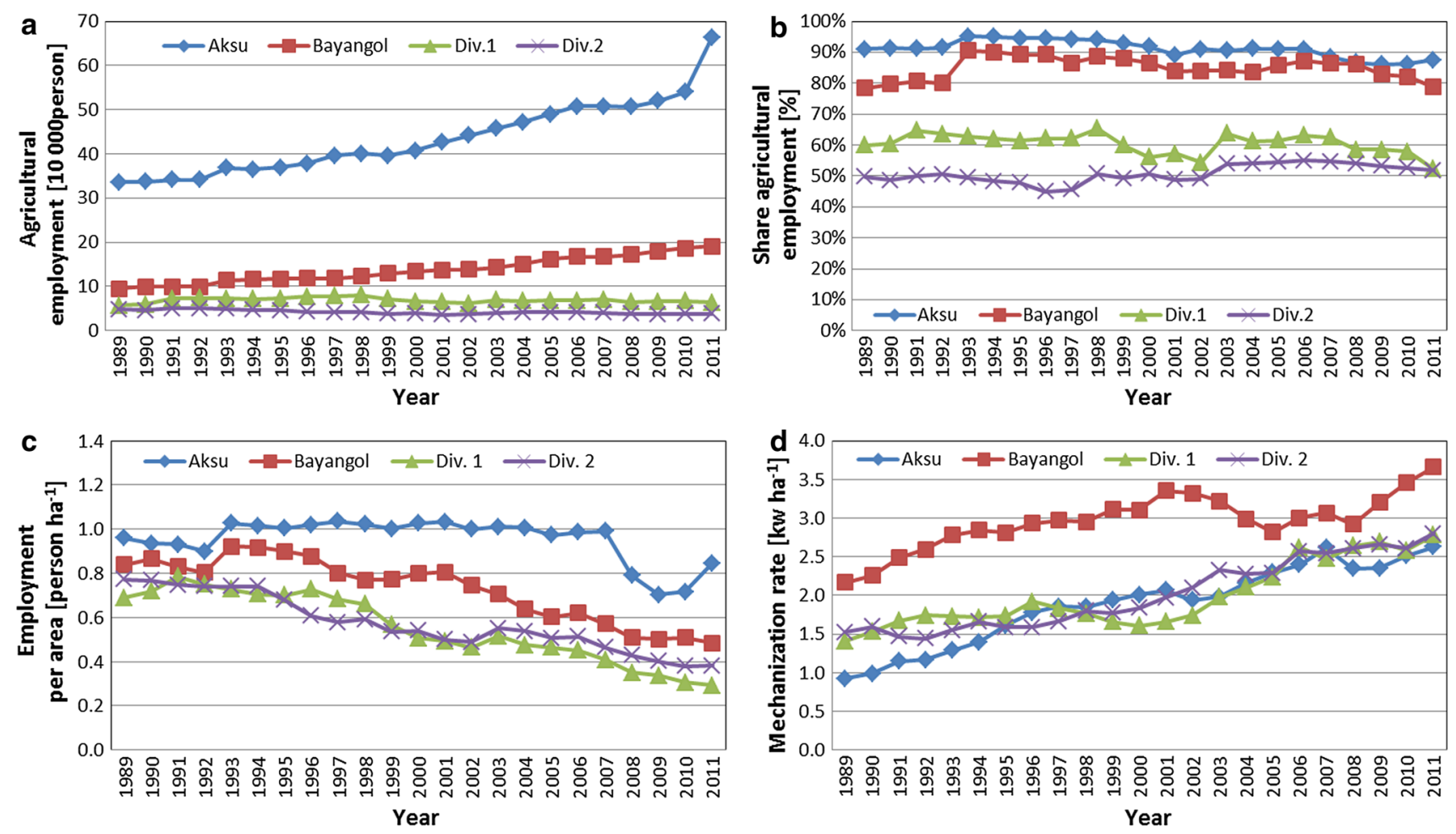

Fig. 4 Development of agricultural employment (a), share of agricultural employment in total employment (b), agricultural employment per agricultural land area (c), and degree of mechanization of

agricultural services play a minor role. In 2011, farming contributed $75-80 \%$ to total agricultural GOV in Aksu, Bayangol, and Div.2, while it was responsible for nearly $90 \%$ of total GOV in Div.1.

The GOV per area (Fig. 5c) developed very positive in the ATR, with the best developments in Div.1, Div.2 and Bayangol, while Aksu lacks far behind. A similar development occurred for the GOV per labor force, with the highest values in Div.1 (95,000 RMB), Div.2 (58,000 RMB) and Bayangol (43,000 RMB) in 2011. Aksu again lags far behind at 12,000 RMB per labor force. The relatively poor performance of Aksu is on one side the result of the high ratio of newly established orchards in Aksu (Fig. 3a), which do not yield high revenues in the first few years after establishment. On the other side, the small land area per farm household is highly unfavorable.

The huge increase in monetary output per land area (Fig. 5c), has to be recognized as a strong trigger of continuous agricultural land expansion in the ATR, by providing the financial resources and strengthening the expectations for high returns of investments for farmers. This is in line with Angelsen (1999) who state that profitability of farming has a strong influence on reclamation of new land. Additionally, Li et al. (2011) confirm that Chinese farmers' land-use decisions are often governed by profit maximization ( $\mathrm{Li}$ et al. 2011).

agriculture in four administrative regions of the ATR during 1989-2011 (compiled from BTSYB 1990-2012 and XJSYB 1990-2012)

Agricultural commodity prices

In the next step, how far economic considerations govern farmers' crop choice in the ATR was assessed. According to Kleiber (2009) and Mullen et al. (2005), farmers' decision on which crop to grow is in large part influenced by its sales price. Therefore, previous years' national commodity prices of cotton, aggregated tree fruits (apple, pear, peach, grape, date), aggregated cereals (barley, wheat, maize), and dates (jujube) obtained from FAOSTAT (2013) were correlated with current year's cultivated area of the respective crop or aggregation of crops within the four administrative regions, as well as the entire ATR (Table 6). A strong positive correlation can be observed in all regions for cotton, and especially for tree fruits and dates, while for cereals no significant correlation exists. Since cotton production is of great strategic importance to China's textile industry ( $\mathrm{Ju}$ et al. 2011), it is stabilized by the government through market control and subsidization of production (Meador and $\mathrm{Wu}$ 2013; Han et al. 2013). This partly explains why correlation coefficient of lagged price and area is not higher than 0.62 . The very high correlation coefficient for tree fruits and dates indicates a strong impact of price on farmers' decision to produce them. Regarding cereal production, there are two reasons for the nonexistent 

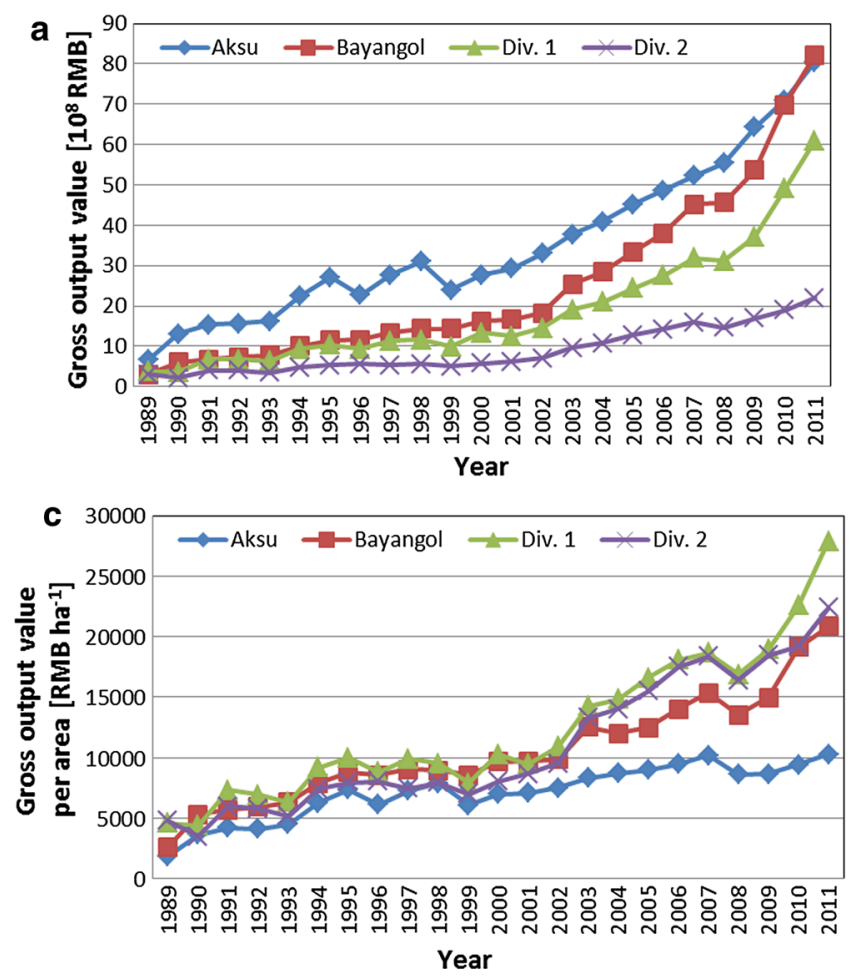

Fig. 5 Development of agricultural gross output value (a), share of farming in total agricultural gross output value (b), gross output value per area (c), and gross output value per laborer (d) in four

correlation. Firstly, the high rates of subsidization, which are paid in the form of direct grain subsidies, quality seed subsidy and input subsidies, buffer the fluctuations in actual market price volatility (Meng 2012). Secondly, but even more important is the fact that cereal producers in China often belong to the more backward and disadvantaged farmers, who neither have the financial resources nor the agronomic skills to opt for the production of alternative cash crops like cotton or fruits in times of low cereal price.

\section{Technological progress and development of natural conditions}

The availability of water resources is a result of changes in natural conditions as well as human activities related to water use. Therefore, the "technological" and "natural" categories of drivers are assessed jointly in the following section.

\section{Agricultural yields}

The level of agricultural yields has a significant impact on resource use efficiency of land and water, and therefore needs to be considered as a vital driver of regional land and water use. In the ATR the yields of the major agricultural crops
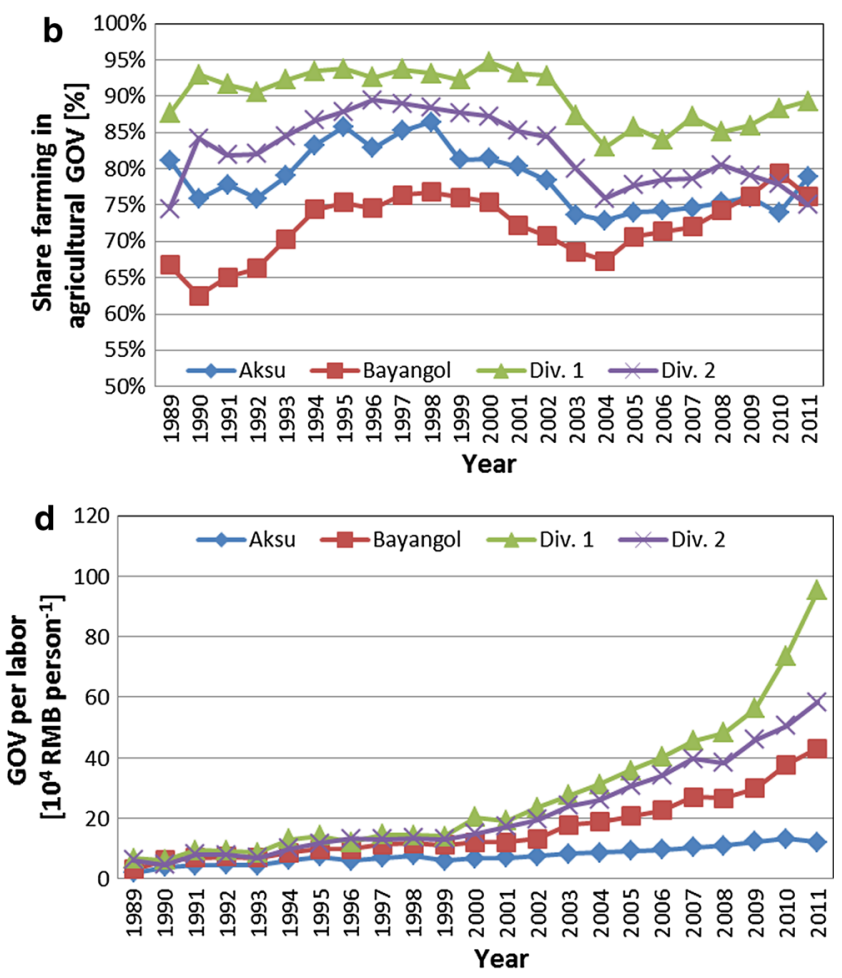

administrative regions of the ATR during 1989-2011 period; monetary values are given in real price (1989 RMB) (compiled from BTSYB 1990-2012 and XJSYB 1990-2012)

Table 6 Pearson correlation coefficient of last year's price and current year's area of major agricultural commodities of the ATR during 1992-2011 period

\begin{tabular}{lcccrr}
\hline Item & Aksu & Bayangol & Div.1 & Div.2 & ATR \\
\hline Seed cotton & 0.56 & 0.62 & 0.69 & 0.81 & 0.62 \\
All tree fruits & 0.90 & 0.89 & 0.88 & 0.90 & 0.91 \\
Dates & 0.90 & 0.82 & 0.87 & 0.87 & 0.90 \\
Cereals & -0.20 & -0.23 & 0.41 & -0.33 & -0.19 \\
\hline
\end{tabular}

experienced strong increases since the late 1990s (Fig. 6). While the yield of cotton is between 0.6 and 1.1 tons per hectare in 1989, average yields per hectare reached 1.7 tons in Aksu, 2.1 tons in Bayangol and more than 2.5 tons in the two divisions in 2011 (Fig. 6a). For cereals a similar increase can be observed, rising from 3 to 4 tons in 1989, to 7.4 tons in Aksu, 6.4 tons in Bayangol, 8.2 tons in Div. 1 and 5.4 tons in Div.2 in 2011 (Fig. 6b). Despite the very positive development over the 22-year period, a slight stagnation of yield levels can be observed in recent years. Nevertheless, yield increase overcompensated the decrease in production area of grains, leading to a slight increase of annual per capita production of grain from 455 to $470 \mathrm{~kg}$ in the ATR from 1989 until 2011. Regarding the yields of fruits and vegetables, no consistent data can be presented. For fruits the high share of recently established non-fruiting plantations, impede the calculation of yields from production amount and area data. 
As all vegetables whether they have very high (e.g. water melons) or very low (e.g. dried chili) per hectare yields, are aggregated in the statistics as "vegetables", and the production of the different vegetables is very distinct between the four regions and changing over time, a comparision of yield levels over regions and years has little validity, and was therefore not conducted.

\section{Availability of land}

Loss of arable land due to increasing industrial, infrastructural and residential area is considered a serious issue in China by many authors, threatening China's food security in the long run (e.g., Lin and Ho 2003; Wang et al. 2012; Zhang 2004). However, Deng et al. (2006) identified a national net increase of agricultural land from 1986 to 2000 , with one of the strongest increases occurring in Xinjiang. This is in line with the strong expansion of cultivated land area in the ATR described above.

Even though industrialization and urbanization in the ATR increased in recent years and this trend is most likely to continue (DRCDO 2011), strong competition for land resources is limited to the few urban areas and industrial centers of the ATR, with the vast majority of cultivated land being unaffected. Furthermore, a range of farmland protection policies were enacted in recent years to prevent massive conversion of arable land towards other uses (Lichtenberg and Ding 2008).

However, arable land in the ATR has other crucial factors limiting its extent. Salinization of agricultural soils, caused by unreasonable irrigation and insufficient drainage, is severely compromising agricultural production. According to Wang et al. (2003) nearly $40 \%$ of arable land in the ATR faces serious salinity problems. To remediate saline land, washing out of salts through extensive flooding is the major choice. Near the headwaters of the river, where sufficient fresh water is available farmers flush their fields frequently. As a consequence, salinity of Tarim River

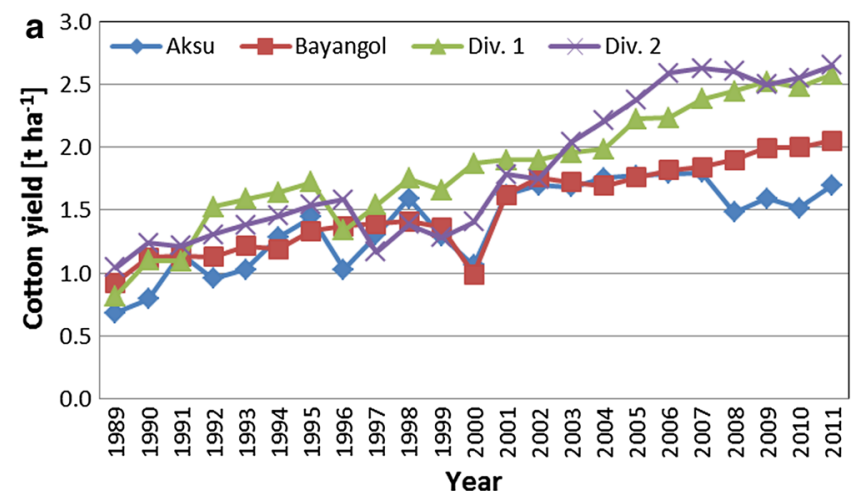

water measured at its starting point in Alar increased from less than 1 to more than $5 \mathrm{~g} / \mathrm{l}$ from 1960 to 2000 (Wang et al. 2010). This qualitative degradation of water resources, along with the fact that a high share of farmers along the middle and lower reaches of Tarim River additionally suffer frequent quantitative water shortage (Thevs 2011) leads to the conclusion that land is not the key limiting factor of development in the region, but water.

Climate change and availability of water resources

Water availability within the ATR is first of all determined by the rivers' water discharge. In a very comprehensive study Xu et al. (2005) determined that a slight increase in temperature over the second half of the last century led to a significant increase in river discharges, mainly caused by increased glacier melt. Precipitation only increased insignificantly in the same period. Especially Aksu River, which contributes in average about $77 \%$ of total water to the Tarim mainstream, experienced a significant increase in runoff in recent years, with a $6.7 \%$ increase for the 1994-2003 period compared to the average of 47 years since 1957. Accordingly, the total annual water volume in the headstreams of Tarim River increased by more than 25 million cubic meters during the 1994-2003 period. Similar increases in Aksu River headstream runoff are reported by Tang and Deng (2010), and Zhang (2001).

Despite the increase in headstream water availability, the mainstream of Tarim River experienced reduced water flow. The annual discharge of Aksu River into the Tarim River decreased from 33.7 million $\mathrm{m}^{3}$ in the 1980 s and 34.1 million $\mathrm{m}^{3}$ in the 1990 s to 26.9 million $\mathrm{m}^{3}$ in the 2000s (Zhang 2001). This discrepancy is obviously caused by the strongly increased water consumption in the headstream areas (Thevs 2011; Turak et al. 2007; Wang et al. 2003; Wu 2012; Xu et al. 2003; Zhang 2001).

In addition, one has to consider that water availability is not only determined by river discharge, but also by water

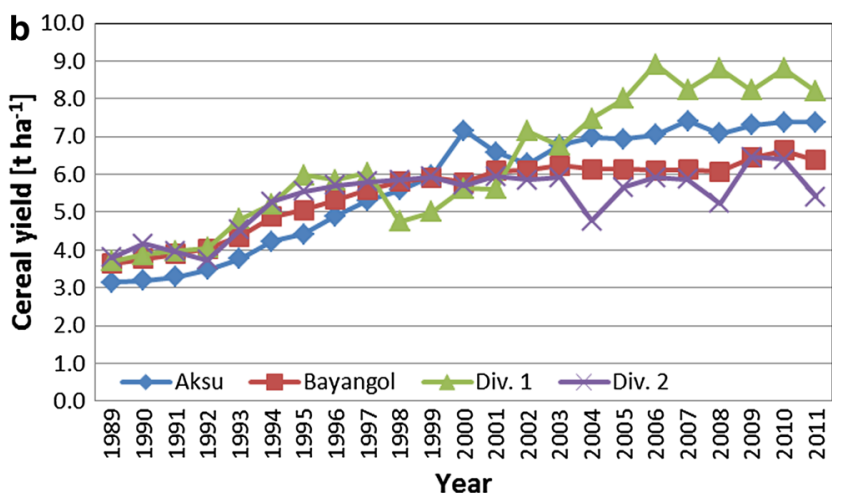

Fig. 6 Development of yields per hectare of cotton (a), and cereals (b) in the four administrative regions of the ATR during 1989-2011 (compiled from BTSYB 1990-2012 and XJSYB 1990-2012) 

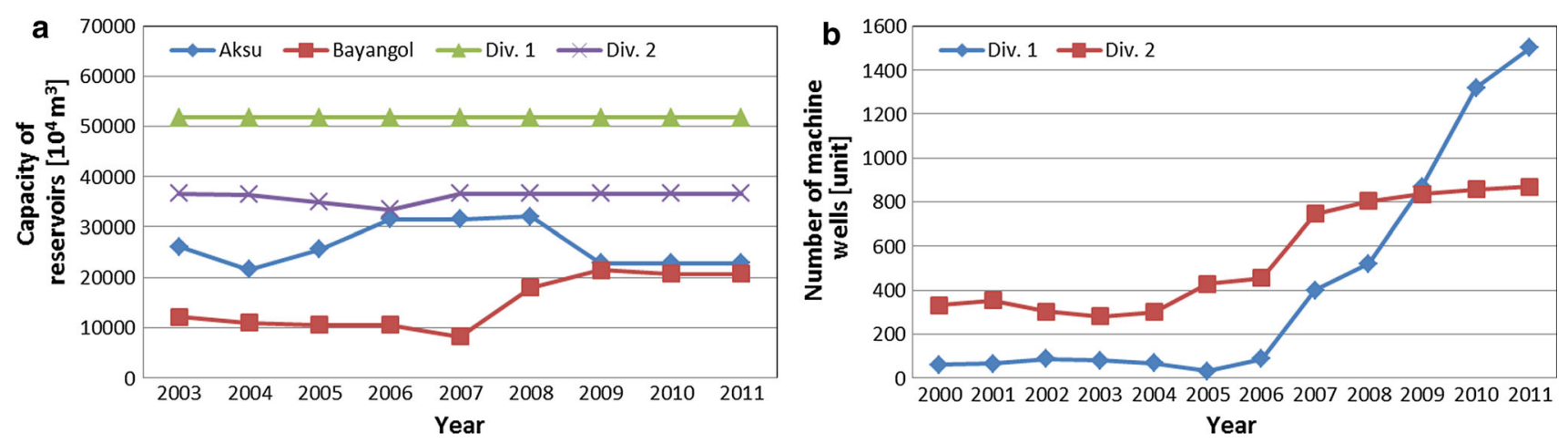

Fig. 7 Development of capacity of reservoirs in the four administrative regions of the ATR (a), and number of machine wells installed in Div.1 and Div.2 (b) over the last decade (compiled from BTSYB 1990-2012 and XJSYB 1990-2012)

Table 7 Planned vs. actual area of fruits and cotton in the four administrative regions of the ATR in 2010 as planned in the 11th FYPs (compiled from BTSYB 2011; DRCAP 2006; DRCBP 2006; DRCDT 2006; XJSYB 2011)

\begin{tabular}{|c|c|c|c|c|c|c|c|c|}
\hline & \multicolumn{4}{|c|}{ Area of fruits in $2010\left(10^{4}\right.$ ha $)$} & \multicolumn{4}{|c|}{ Area of cotton in $2010\left(10^{4} \mathrm{ha}\right)$} \\
\hline & Aksu & Bayangol & Div.1 & Div. 2 & Aksu & Bayangol & Div.1 & Div. 2 \\
\hline Planned & 166.4 & 66.7 & $\mathrm{nn}$ & 40.0 & 200 & 93.3 & $\mathrm{nn}$ & $\mathrm{nn}$ \\
\hline Actual & 181.0 & 86.7 & 52.1 & 33.1 & 300 & 150.5 & 118.5 & 27.1 \\
\hline Planned vs. actual (\%) & 8.8 & 30.1 & $\mathrm{nn}$ & -17.3 & 50.0 & $61 \%$ & $\mathrm{nn}$ & $\mathrm{nn}$ \\
\hline
\end{tabular}

storage infrastructure as well as drilling facilities for abstraction of groundwater. Related data are limited, both in time and space. The capacity of reservoirs was very stable in the two divisions since 2003, while it increased strongly in Bayangol since 2007, and declined slightly in Aksu until 2011 (Fig. 7a). Compared to the huge increase of agricultural land-use area in the same period (Figs. 2a, $3 a)$, a tremendous decrease in storage capacity per land area has to be recognized. Partly this decline may have been buffered by the increased use of groundwater, which is indicated by the rapid increase in machine wells installed in Div.1 and Div.2 since 2005 (Fig. 7b). For Aksu and Bayangol no yearbook data are available. However, a further increase in "utilization of groundwater resources" is planned in Aksu during 12th FYP period (DRCAP 2011).

The impact of water availability on agricultural land area development is impressively revealed when comparing the planned and actual area of fruits and cotton in the ATR (Table 7). While Aksu and Bayangol, feeding not only on the Aksu River, but also on numerous smaller rivers like Weigan, Kaidu and Konqi River, strongly exceeded their development goals of fruit and cotton area, as planned in their 11th FYPs, Div.2 significantly failed its target of fruit production area for 2010. Being mainly located at the lower reaches of the Tarim River, Div.2 solely depends on its surface water provision. Only Konqui River water is additionally allocated from time to time to Div.2; however, the amount is strongly limited by the increasing water demand of the booming city of Korla. Thus, lack of water resources is ranked first in its recent FYP under the challenges faced, being recognized as "seriously affecting economic development" (DRCDT 2006).

When looking at the role that water resource conditions play in land and water use in the ATR as a whole, one has to recognize that the improved water availability in the upper reaches resulted in better production conditions for farmers and related increased agricultural profitability, leading to reclamation of new land, which finally induced a decline in water availability in the lower reaches. This development might have been further intensified by migration towards the headstreams of the rivers, which feature abundant water.

Even though prefectural governments strive to "stabilize" agricultural production areas (e.g., DRCAP 2006; DRCBP 2006), being aware that the further expansion of land worsens the tight water resource situation, the targets were heavily exceeded during the past FYP period (see Table 7). Moreover, the official ordinances enacted on the regional level to control the expansion of agricultural land (SCXPC 1997) and restrict the extraction of groundwater (TRBMB 2008) showed limited success. The implementation of such regulations is to a large part the responsibility of local administrators. For them it is very difficult to effectuate ordinances, which-as a negative externalityrestrict local people from improving their economic situation (Zhang et al. 2009). 

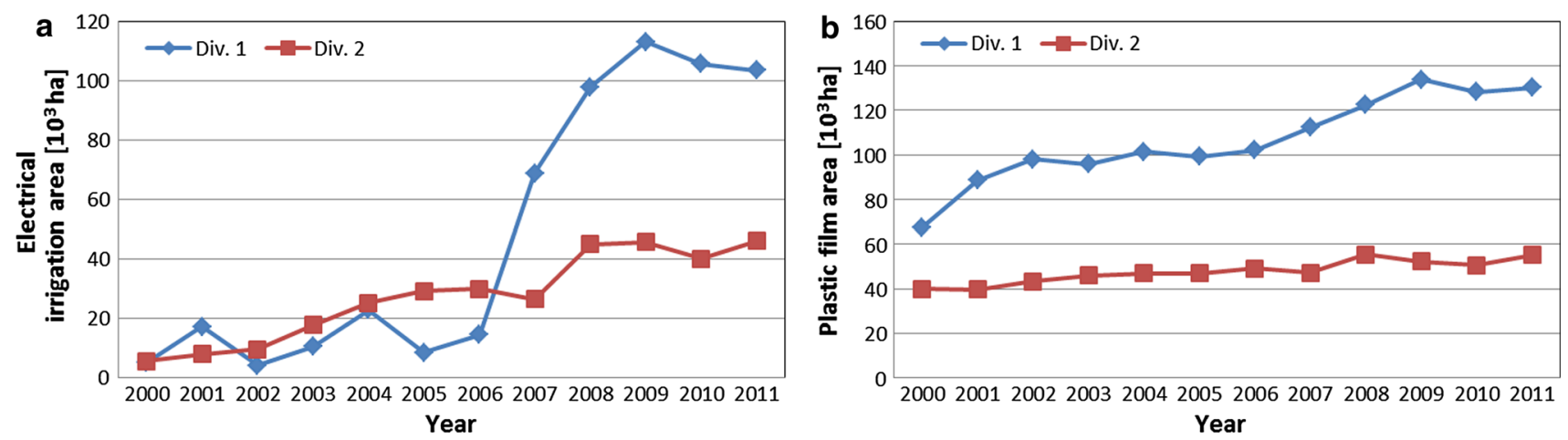

Fig. 8 Development of area under advanced irrigation technology (a) and plastic mulch (b) in Div.1 and Div.2 during 2000-2011(compiled from BTSYB 1990-2012)

Water-use technology

Throughout the ATR strong efforts are undertaken to increase the area of cultivated land using advanced irrigation technology, with reliable data available only for Div.1 and Div.2 (Fig. 8). Both drip irrigation and plastic mulching area increased over the last decade with the increases being much stronger in Div.1. In the 11th and 12th FYPs of all regions, intents are formulated to reduce water losses by increasing the area using advanced irrigation measures. In this respect, Bayangol prefecture plans to increase the "high-efficiency water-saving area" to more than 5,000 ha and achieve a gross irrigation quota below 9,000 $\mathrm{m}^{3}$ per hectare (DRCBP 2011).

However, it is vital to recognize that the sole increase of application of drip irrigation technology by the local farmers can only be a small part of the solution to realize a sustainable water resource use along the Tarim River.

\section{Afforestation programs}

Even though not mentioned by the local experts, China's massive afforestation programs have to be recognized as another vital land-use driver in the ATR, being responsible for a great share of the increase in man-made forest area (Fig. 3b). Among them the "Three-North Shelterbelt Forest Program" and the "Grain-for-Green Program" (GFG) are the most prominent, with the latter having by far the strongest impact in the ATR. Implemented nationwide in 2001, GFG aims at returning farm land to forest to control erosion while supporting rural development (Cao et al. 2011; Fang et al. 2012). Farmers receive subsidies in the form of money or grain for the first five and eight years after conversion into economic (orchards) and ecological forest, respectively. At least $80 \%$ of land needs to be converted to ecological forest, with not more than $20 \%$ converted to economic forest (Liu and $\mathrm{Wu} 2010$ ).

Even though GFG and other afforestation programs follow very honorable motives and desirable goals, Cao et al. (2011) claim that their massive extent may have overshot the target, resulting in ecological deterioration especially in arid and semi-arid regions of China (Zhang and Sun 2003). This may as well be the case in the ATR, where water is the scarcest resource, and its overuse causes severe environmental degradation (Thevs 2011; Xu et al. 2005). Even though wind erosion in the afforested areas along the headstream waters in Aksu and Div.1 may be controlled effectively, the degradation of natural riparian ecosystems down the river caused by reduced water supply may lead to a strong overall increase of erosion.

For the ATR one additionally has to recognize that the huge implementation of GFG-area did not lead to a reduction or at least stagnation in area used for annual crops. Since 1989 all three categories of land use, namely annual crops, orchards and ecological man-made forest increased.

Ecological water demand and water conveyances

Not apparent at first glance and overlooked by the local experts, the water demand of the natural ecosystems in the ATR needs to be considered another driving factor. As a result of ever increasing human activities and related water exploitation since the middle of last century, the ecological water requirements of the ATR could not be met (Deng et al. 2013; Thevs 2011; Ye et al. 2010). Since the construction of Daxihaizi water reservoir in 1972, the lowest $350 \mathrm{~km}$ of the Tarim received hardly any runoff (Song et al. 2000). As a consequence, groundwater levels declined leading to a steady decay of the natural vegetation (Chen et al. 2013; Huang and Pang 2010; Ye et al. 2010).

To maintain a "green corridor" between the Taklimakan and the Kuluk deserts, and protect important infrastructure from wind erosion and desertification, the Chinese government launched the biggest water diversion project in western China in 2000 (Hou et al. 2007). From beginning of 2000 to the end of 2011 more than $28 \times 10^{8} \mathrm{~m}^{3}$ of water was allocated in 12 ecological water diversion campaigns 
Table 8 Development of water use per area $\left(\mathrm{m}^{3} \mathrm{ha}^{-1}\right)$ and productivity of agricultural water (GDP per invested unit of water and labor) $\left(\mathrm{RMB} \mathrm{m}^{-3}\right.$ person $^{-1}$ ) in agricultural sector of Aksu and Bayangol during 2004-2010; GDP given in real price (2004 RMB) (calculated from XJSYB 2005-2012)

\begin{tabular}{lllll}
\hline & \multicolumn{2}{l}{ Water use per area $\left(\mathrm{m}^{3} \mathrm{ha}^{-1}\right)$} & & \multicolumn{2}{l}{ Water productivity $\left(\mathrm{RMB} \mathrm{m}^{-3} \mathrm{person}^{-1}\right)$} \\
\cline { 2 - 3 } \cline { 5 - 5 } & Aksu & Bayangol & Aksu & Bayangol \\
\hline 2004 & 20,951 & 15,986 & 167 & 948 \\
Annual increase (\%) & 12,966 & 11,185 & 256 & 1,748 \\
\hline
\end{tabular}

to the lower reaches of the Tarim (Aishan et al. 2013a). The water is mainly diverted from Bosten Lake, located in the Kaidu-Konqi watershed (Hou et al. 2007). The impact of the project on the ground water developments and the riparian ecosystem are in the focus of several research groups, and have been published in numerous articles (e.g., Aishan et al. 2013b; Chen et al. 2013; Xu et al. 2012). The research findings attest a remarkable revitalization of riparian ecosystems as a consequence of water diversion. However, the positive effects concentrate on the first $200 \mathrm{~m}$ close to the river (Aishan et al. 2013b), and are mostly limited to the already existing tree stock. Rejuvenation of the riparian forests through successful establishment of tree seedlings is still negligible (Zhao et al. 2006).

To maintain an intact riparian ecosystem in the long run, Wang and $\mathrm{Lu}$ (2009) recommend a restoration and stabilization of the groundwater table at about $4 \mathrm{~m}$ depth. To achieve this, a delivery of about $2.5 \times 10^{8} \mathrm{~m}^{3} \mathrm{a}^{-1}$ to the lower reaches would be necessary during the first 5 years of restoration, followed by $2.0 \times 10^{8} \mathrm{~m}^{3} \mathrm{a}^{-1}$ from then on. From the 12 water diversion campaigns conducted since 2000 , six did not reach the level of $2.5 \times 10^{8} \mathrm{~m}^{3} \mathrm{a}^{-1}$ (Aishan et al. 2013a). To close the gap between necessary and available water resources for ecological restoration of the lower Tarim, the responsible administrative bodies might extend the water source from Bosten Lake to the upper Tarim and Aksu River in the future; this would result in reduced water availability for human activities in those areas.

\section{Water-use efficiency}

Finally, the actual water resource use efficiency within the ATR is assessed. As official water-use data are not available for the two divisions, the analyses focuses on Aksu and Bayangol. On the first glance Aksu, located at the upper reaches of the ATR, and thus abundant in water resources, shows a very positive development over the last two decades. Cultivated land area increased strongest of all four sub-regions (Figs. 2a, 3a), and agricultural yields did not differ significantly from those of Bayangol prefecture (Fig. 6). At the same time the water use per area improved strongly since 2004 reaching a similar level as in Bayangol (Table 8) in 2010.
However, as water scarcity has to be recognized the bottle neck for regional development, with the vast majority of rural population being employed in the agricultural sector, and thus depending on this scarce water for living, it is essential to consider the productivity of agricultural water as a key variable for sustainable development. Agricultural water productivity is therefore defined as agricultural GDP per invested unit of water and labor force. Due to the strong increase in population (Table 4) and consequential agricultural employment (Fig. 4a), coupled with a fairly low monetary output per labor force (Fig. 4d), Aksu features a seven times lower water productivity compared to Bayangol in 2011 (Table 8).

It becomes obvious that the implementation of watersaving irrigation technology and related improvement of water use per area is not the universal remedy to reduce overuse of water resources and maximize regional benefits. Bayangol recognized the necessary development steps already in its 11th FYP, aiming at the increase of farm land per farm household by moving agricultural labor into other sectors (DRCBP 2006). Additionally, its share of laborintensive and high-value crops like vegetables (Fig. 2d) increased sharply in recent years, which strongly contributed to increasing its agricultural water productivity.

A much more efficient water use compared to the agricultural sector was achieved in the other two sectors of economy in both prefectures (Table 9). Compared to the agricultural sector, the monetary output per invested unit of water in 2010 was more than 100 times higher in the industrial and construction (secondary) sector and even 400-900 times higher in the service (tertiary) sector in Bayangol and Aksu, respectively. Therefore, the attempts to move labor out of agriculture into other sectors of industry, described in detail above, should receive maximum efforts by local governments.

\section{Conclusions and recommendations}

From 1989 until 2011 a tremendous increase in land and water use for agriculture can be observed in most regions of the ATR. The analysis shows that this development is a result of the interaction of (1) vast population growth and 
Table 9 Development of GDP per invested unit of water $\left(\mathrm{RMB} \mathrm{m}^{-3}\right)$ for the three sectors of industry in Aksu and Bayangol during 2004-2010; GDP given in real price (2004 RMB) (calculated from XJSYB 2005-2012)

\begin{tabular}{|c|c|c|c|c|c|c|c|c|}
\hline & \multicolumn{8}{|c|}{ Water productivity $\left(\mathrm{RMB}^{-3}\right)$ in different sectors of industry } \\
\hline & \multicolumn{2}{|l|}{ Total } & \multicolumn{2}{|c|}{ Primary sector } & \multicolumn{2}{|c|}{ Secondary sector } & \multicolumn{2}{|c|}{ Tertiary sector } \\
\hline & Aksu & Bayangol & Aksu & Bayangol & Aksu & Bayangol & Aksu & Bayangol \\
\hline 2004 & 1.5 & 5.6 & 0.6 & 1.1 & 41.0 & 188.3 & 90.9 & 88.3 \\
\hline 2010 & 2.8 & 12.0 & 0.9 & 2.2 & 105.6 & 258.3 & 803.1 & 891.3 \\
\hline Annual increase $(\%)$ & 13.6 & 18.7 & 7.7 & 17.4 & 26.2 & 6.2 & 130.5 & 151.6 \\
\hline
\end{tabular}

related increase in agricultural labor; (2) positive price developments for fruits and cotton; (3) strong increase in profitability of agriculture, triggering the reclamation of more land; (4) afforestation programs pushing for the establishment of orchards; and (5) insufficient restriction of agricultural land expansion. As a consequence, reduced water availability in the lower reaches of the river impairs the development in Div.2, which faces declining agricultural production area and outflow of people in recent years. Even though strong efforts to promote water-saving irrigation technology exist, the improvements in water-use efficiency per land area are far from sufficient to outweigh the expansion of agricultural land and especially the increasing number of farmers depending on the scarce water resources throughout the ATR. Thus, the local governments and administrators need to step up their efforts to move people out of agriculture, increase agricultural area per farm household without further reclamation of land, and significantly improve agricultural water productivity by increasing yield levels and shifting crop production towards labor-intensive high-value commodities like vegetables. Additionally, the further development of second and third industrial sector offers great opportunities to increase gross regional product, while decreasing overall water consumption for human purposes. Apart from tackling high fertility as cause of overpopulation, effective control of immigration should also be put on the agenda. Only then can the ecological water demand along the river be met, without comprising the local population's aspirations.

Acknowledgments This research was embedded in the Sustainable Management of River Oases along the Tarim River (SuMaRiO) project, funded by the German Federal Ministry of Education and Research through the "Sustainable Land Management" program. We furthermore want to express our deep gratitude to Dr. Yiliminuer Imit of SuMaRiO subproject 1.3 for her great support in organizing the expert workshop in Urumqi. Finally, we highly acknowledge the valuable suggestions provided by five anonymous reviewers.

Open Access This article is distributed under the terms of the Creative Commons Attribution License which permits any use, distribution, and reproduction in any medium, provided the original author(s) and the source are credited.

\section{References}

Aishan T, Halik Ü, Cyffka B, Kuba M, Abliz A, Baidourela A (2013a) Monitoring the hydrological and ecological response to water diversion in the lower reaches of the Tarim River, Northwest China. Quat Int 311:155-162

Aishan T, Halik Ü, Kurban A, Cyffka B, Kuba M, Betz F (2013b) Eco-morphological response of floodplain forests (Populus euphratica Oliv.) to manmade water diversion in the lower reaches of Tarim River, Xinjiang, Northwest China. Environ Earth Sci. doi:10.1007/s12665-013-3033-4

Angelsen A (1999) Agricultural expansion and deforestation: modeling the impact of population, market forces and property rights. J Dev Econ 58:185-218

Attane I, Courbage Y (2000) Transitional stages and identity boundaries: the case of ethnic minorities in China. Popul Environ 21(3):257-280

Bai Y, Xu H, Ling H (2013) Drought-flood variation and its correlation with runoff in the three headstreams of Tarim River, Xinjiang, China. Environ Earth Sci 71:1297-1309

Barbier EB (2004) Agricultural expansion, resource booms and growth in Latin America: implications for long-run economic development. World Dev 32(1):137-157

BTSYB (1990-2012) Bingtuan statistical yearbook, National Bureau of Statistics. China Statistical Press, Beijing

Cote I (2011) Political mobilization of a regional minority: han Chinese settlers in Xinjiang. Ethnic and Racial Stud 34(11):1855-1873

Cao S, Chen L, Shankman D, Wang C, Wang X, Zhang H (2011) Excessive reliance on afforestation in China's arid and semi-arid regions: lessons in ecological restoration. Earth Sci Rev 104:240-245

Chen Y, Ye Z, Shen Y (2011) Desiccation of the Tarim River, Xinjiang, China, and mitigation strategy. Quartern Int 244:264-271

Chen Y, Li W, Xu C, Ye Z, Chen Y (2013) Desert riparian vegetation and groundwater in the lower reaches of the Tarim River Basin. Environ Earth Sci. doi:10.1007/s12665-013-3002-y

CSYB (2012) China statistical yearbook, National Bureau of Statistics. China Statistical Press, Beijing

de la Paix MJ, Li L, Ge J, de Dieu HJ, Theoneste N (2012) Analysis of snowmelt model for flood forecast for water in arid zone: case of Tarim River in Northwest China. Environ Earth Sci 66(5):1423-1429

Deng X, Huang J, Rozelle S, Uchida E (2006) Cultivated land conversion and potential agricultural productivity. Land Use Policy 23:372-384

Deng X, Xu H, Yang Z, Ling H, Fu J (2013) Distribution characters and ecological water requirements of natural vegetation in the upper and middle reaches of Tarim River, Northwestern China. J Food Agric Environ 11(2):1156-1163 
DRCAP (Development and Reform Commission of Aksu Prefecture) (2006) The eleventh five-year plan for national economic and social development of Aksu Prefecture (in Chinese). http://fgw. aks.gov.cn/page.asp?id=45. Accessed 12 Jun 2013

DRCAP (Development and Reform Commission of Aksu Prefecture) (2011) The twelfth five-year plan for national economic and social development of Aksu Prefecture (in Chinese). http://fgw. aks.gov.cn/page.asp?id=47. Accessed 12 Jun 2013

DRCBP (Development and Reform Commission of Bayangol Prefecture) (2006) The eleventh five-year plan for national economic and social development of Bayingol Prefecture (in Chinese). http://bzfgw.bzjj.gov.cn/html/zzhzgh/2008-11/18/ 2008 11_18_198.html. Accessed 11 April 2013

DRCBP (Development and Reform Commission of Bayangol Prefecture) (2011) The twelfth five-year plan for national economic and social development of Bayingol Prefecture (in Chinese). http://zsj.xjbz.gov.cn/news/?135_925.html. Accessed 12 Jun 2013

DRCDO (Development and Reform Commission of Xinjiang Production and Construction Corps Division 1) (2011) The twelfth five-year plan for national economic and social development of the Division 1 (in Chinese). http://www.ale.gov.cn/structure/ xxgk/ghjhzw_30436_1.htm. Accessed 23 Apr 2013

DRCDT (Development and Reform Commission of Xinjiang Production and Construction Corps Division 2) (2006) The eleventh five-year plan for national economic and social development of the Division 2 (in Chinese). http://www.nes.gov.cn/10017/ 10290/10017/2008/18996_5.htm. Accessed 22 Apr 2013

Fan CC (2005) Interprovincial Migration, population Redistribution, and Regional Development in China: 1990 and 2000 Census Comparisons. Prof Geogr 57(2):295-311

Fang S, Yang W, Zhang X (2012) Assessment of farmland afforestation in the upstream Yangtze River, China. Outlook Agric 41(2):97-101

FAOSTAT (Food and Agriculture Organization of the United Nations Statistical Database) (2013). http://faostat3.fao.org/home/index. html. Accessed 19 Feb 2013

Feike T, Doluschitz R, Chen Q, Graeff-Hönninger S, Claupein W (2012) How to overcome the slow death of intercropping in the North China Plain. Sustainability 4(10):2550-2565

Han G, Zheng J, Lu J (2013) Research on the size of inter-provincial allocation of subsidies for cotton production in China. Xitong Gongcheng Lilun yu Shijian/Syst Eng Theory Pract 33(1):41-49 (in Chinese)

Hao X, Li W, Huang X, Zhu C, Ma J (2010) Assessment of the groundwater threshold of desert riparian forest vegetation along the middle and lower reaches of the Tarim River, China. Hydrol Process 24:178-186

Hou P, Beeton RJS, Carter RW, Dong XG, Li (2007) Response to environmental flows in the lower Tarim River, Xinjiang, China: Ground water. J Environ Manag 83:371-382

Huang T, Pang Z (2010) Changes in groundwater induced by water diversion in the lower Tarim River, Xinjiang Uygur, NW China: evidence from environmental isotopes and water chemistry. J Hydrol 387:188-201

Ju Y, Dai T, Rui W, Yi J, Jing W (2011) Research on market efficiency of Chinese cotton market. In: Proceedings of the 2011 International Conference on Business Computing and Global Informatization, vol 6003822, pp 43-46

Kleiber K (2009) The effect of ethanol-driven corn demand on crop choice, No 49616, 2009 Annual Meeting, July 26-28, 2009, Milwaukee, Wisconsin, Agricultural and Applied Economics Association. http://EconPapers.repec.org/RePEc:ags:aaea09: 49616. Accessed 16 Jun 2013

Lichtenberg E, Ding C (2008) Assessing farmland protection policy in China. Land Use Policy 25:59-68
Li C, Kong X, Liang Y, Liu B, Tan M, Li T (2011) Analysis of decision-making mechanism of arable land use based on household object in Jingji plains. Nongye Gongcheng Xuebao/ Trans Chin Soc Agric Eng 27(9):316-322 (in Chinese)

Lin GCS, Ho SPS (2003) China's land resources and land use change: insights from the 1996 land survey. Land Use Policy 20:87-107

Liu C, Wu B (2010) Grain for Green Programme in China: policy making and implementation? The University of Nottingham, China Policy Institute. Briefing Ser (60):1-17. http://www. nottingham.ac.uk/cpi/documents/briefings/briefing-60-reforesta tion.pdf. Accessed 12 Jul 2013

Liu T, Fang H, Willems P, Bao AM, Chen X, Veroustraete F, Dong QH (2013) On the relationship between historical land-use change and water availability: the case of the lower Tarim River region in Northwestern China. Hydrol Process 27(2):251-261

Meador M, Wu X (2013) Cotton and products annual, ChinaPeoples Republic of. USDA, GAIN Report Number: 13017. http://gain.fas.usda.gov/Recent\%20GAIN\%20Publications/Cotton $\% 20$ and\%20Products\%20Annual_Beijing_China\%20-\%20Peo ples\%20Republic\%20of_4-2-2013.pdf. Accessed 9 Jul 2013

Meng L (2012) Can grain subsidies impede rural-urban migration in hinterland China? Evidence from field surveys. China Econ Rev 23:729-741

Mullen JD, Escalante C, Hoogenboom G, Yu Y (2005) Determinants of irrigation farmers' crop choice and acreage allocation decisions: opportunities for extension service delivery. J Ext (on-line), 43(5). http://www.joe.org/joe/2005october/rb3.php. Accessed 8 Jul 2013

NHFPC (National Health and Family Planning Commission of the People's Republic of China) (2002) population and family planning regulation of Xinjiang Uyghur Autonomous Region. http://www.moh.gov.cn/zhuzhan/dftl/201304/155c4234f993487 b9882d97bf360c497.shtml. Accessed 4 Jul 2013 (in Chinese)

SCXPC (Standing Committee of Xinjiang People's Congress) (1997) Regulation of Tarim River Basin on water resources management, Xinjiang People's Publishing House, Urumqi. http://www. tahe.gov.cn/e/action/ShowInfo.php?classid=106\&id=14275. Accessed 11 Jul 2013 (in Chinese)

Song Y, Fan Z, Lei Z (2000) Research on water resources and ecology of Tarim River, China. Xinjiang People's Press, Urumqi (in Chinese)

Su P, Liu X (2005) Photosynthetic characteristics of linze jujube in conditions of high temperature and irradiation. Sci Hortic 104:339-350

Tang D, Deng M (2010) On the management of water rights in the Tarim River Basin (in Chinese). China Water Power Press, Beijing (in Chinese)

Thevs N (2011) Water scarcity and allocation in the Tarim Basin: decision structures and adaptations on the local level. J Curr Chin Affairs 40(3):113-137

TRBMB (Tarim River Basin Management Bureau) (2008) Tarim River Basin Management Bureau strengthens protection and management of the Tarim River Basin watercourses and groundwater management within the Basin, Xinjiang Tarim River Basin Management Bureau, Korla. http://www.tahe.gov. $\mathrm{cn} / \mathrm{e} / \mathrm{action} /$ ShowInfo.php?classid=65\&id=8828. Accessed 11 Jul 2013 (in Chinese)

Turak A, Mamat A, Rusul T, Wang X, Shen Y, Mao W, Wang S (2007) Recent changes in the river hydrological characteristics of the Tarim River Basin. J Glaciol Geocryol 29(4):543-552 (in Chinese)

Wang R, Lu X (2009) Quantitative estimation models and their application of ecological water use at basin scale. Water Resour Manag 23:1351-1365

Wang S, Li H, Xu Z, Han P, Wang J (2003) Flood detention region in the middle reaches of Tarim River mainstream and its impact on 
ecological environments. J Glaciol Geocryol 25(6):712-718 (in Chinese)

Wang X, Zheng D, Shen Y (2007) Land use change and its driving forces on the Tibetan plateau during 1990-2000. Catena 72:56-66

Wang Y, Xi X, Li Y, Xu H (2008) Analysis of the land-using and environmental effect in the middle reach of the Tarim River. J Anhui Agric Sci 36(15):6434-6436 (in Chinese)

Wang G, Shen Y, Zhang J, Wang S, Mao W (2010) The effects of human activities on oasis climate and hydrologic environment in the Aksu River Basin, Xinjiang, China. Environ Earth Sci 59(8):1759-1769

Wang J, Chen Y, Shao X, Zhang Y, Cao Y (2012) Land-use changes and policy dimension driving forces in China: present, trend and future. Land Use Policy 29:737-749

Wu J (2012) Evaluation of the water resource reproducible ability on Tarim River Basin in south of Xinjiang, northwest China. Environ Earth Sci 66(7):1731-1737

XJSYB (1990-2012) Xinjiang statistical yearbook, National Bureau of Statistics. China Statistical Press, Beijing

XPCCIO (Xinjiang Production and Construction Corps Information Office) (2010) Xinjiang production and construction corps, China. Xinjiang Production and Construction Corps Publishing House, Urumqi

Xu H, Song Y, Chen Y (2003) Dynamic change of groundwater after ecological water transport at the lower reaches of Tarim River. China Environ Sci 23(3):327-332 (in Chinese)

$\mathrm{Xu} \mathrm{H}$, Ye M, Song Y (2005) The dynamic variation of water resources and its tendency in the Tarim River Basin. J Geog Sci 15(4):467-474

Xu H, Chen Y, Li W, Zhang L, Hong Y, Bi X, Yang Y (2012) Statistical analysis of groundwater chemistry of the Tarim River lower reaches, Northwest China. Environ Earth Sci 65(6):1807-1820

Yang H, Li x (2000) Cultivated land and food supply in China. Land Use Policy 17:73-88
Ye Z, Chen Y, Li W (2010) Ecological water demand of natural vegetation in the lower Tarim River. J Geogr Sci 20(2):261-272

Yue BL, Su ZX (2002) Ecological suggestion in reforestation (in Chinese). J Sichuan Teachers Coll 23(1):75-78 (in Chinese)

Zhang HM (2001) Study of the problems on pilot engineering of returning agricultural land to forest land or grass land in Sichuan province. For Invent Plan 26(4):44-48 (in Chinese)

Zhang L (2004) Economic development and land-use conversion in the main course area of the Yangtze River Basin. Géocarrefour 79(1):13-18

Zhang L, Sun Y (2003) Efficiency of the Three-North Forest Shelterbelt Program. Acta Sci Nat Univ Pekinensis 39(4):594-600 (in Chinese)

Zhang H, Wu J, Zheng Q, Yu Y (2003) A preliminary study of oasis evolution in the Tarim Basin, Xinjiang, China. J Arid Environ 55:545-553

Zhang J, Zhang F, Zhang L, Wang W (2009) Transaction costs in water markets in the Heihe River Basin in Northwest China. Water Resour Dev 25(1):95-105

Zhao Z, Wang R, Sun H, Zhang H (2006) Assessment of waterrecharging based on ecological features of riparian forest in the lower reaches of Tarim River. Chin Sci Bull 51(1):37-42

Zhao R, Chen Y, Shi P, Zhang L, Pan J, Zhao H (2013) Land use and land cover change and driving mechanism in the arid inland river basin: a case study of Tarim River, Xinjiang, China. Environ Earth Sci 68(2):591-604

Zhou Y, Wang J, Ma A, Qi Y, Bayea (2003) Study on land use dynamics based on RS and GIS in Linze County. J Desert Res 23(2):142-146 (in Chinese)

Zhou H, Zhang X, Xu H, Ling H, Yu P (2012) Influence of climate change and human activities on Tarim River runoffs in China over the past half century. Environ Earth Sci 67(1):231-241 